\title{
KOMPARASI METODE E-SERVQUAL DAN EUCS UNTUK MENGANALISIS TINGKAT KEPUASAN DOSEN DALAM PERKULIAHAN ONLINE PADA MASA PANDEMI COVID-19 BERBASIS LMS DI UMKT
}

\author{
Taghfirul Azhima Yoga Siswa ${ }^{1}$, Naufal Azmi Verdikha ${ }^{2}$ \\ Universitas Muhammadiyah Kalimantan Timur ${ }^{1,2}$ \\ Jl. Ir. H. Juanda No. 15 Samarinda \\ Sur-el : tay758@umkt.ac.id ${ }^{1}$, nav651@umkt.ac.id ${ }^{2}$
}

\begin{abstract}
Muhammadiyah University of East Kalimantan (UMKT) carries the concept of ITBased Paperless University and seeks to implement ideal online lectures using a website/mobilebased Learning Management System (LMS) in collaboration with Openlearning.com Australia. It is hoped that the teaching and learning process can be carried out anytime and anywhere without being limited by space and time but still prioritizing the standards and quality of lectures in accordance with applicable rules. This research was conducted by distributing questionnaires to respondents, namely lecturers as users of LMS Openlearning and selecting respondents using random sampling techniques and the Slovin formula so that 114 people were obtained to be used as samples in this study. The questionnaire distributed consists of two instruments, namely based on the dimensions of the EUCS method and E-ServQual. The purpose of this study was to determine the percentage of lecturer satisfaction levels in implementing open learning for the online lecture process as measured by comparative analysis of the EUCS and E-ServQual method approaches as well as the gap between the two questionnaires, so that it is hoped that it can provide recommendations for the University of Muhammadiyah East Kalimantan to evaluate the success of online lectures that are already running. The results showed that the level of satisfaction of UMKT lecturers in online lectures based on LMS Open learning using the EUCS method was $78.33 \%$ with a difference of $9.98 \%$, while when using the E-ServQual method the level of user satisfaction was $73.15 \%$ with a difference of $8 \%$. From the results of the comparative analysis of the two methods, the percentage of user satisfaction using the EUCS method is higher than the E-ServQual method even though it has the same category range, namely satisfied.
\end{abstract}

Keywords: Learning Management System, E-Servqual, EUCS, User Satisfaction

\begin{abstract}
Abstrak :Universitas Muhammadiyah Kalimantan Timur (UMKT) merupakan Universitas yang mengusung konsep IT-Based Paperless University berupaya menerapkan perkuliahan online yang ideal dengan menggunakan Learning Management System (LMS) berbasis website / mobile yang bekerja sama dengan Openlearning.com Australia. Harapannya proses belajar mengajar dapat dilakukan kapan saja dan dimana saja tanpa dibatasi ruang dan waktu namun tetap mengedepankan standar dan kualitas perkuliahan yang sesuai dengan aturan yang berlaku. Penelitian ini dilakukan dengan cara menyebarkan kuesioner kepada responden yaitu dosen sebagai pengguna LMS Openlearning dan dilakukan pemilihan responden dengan teknik random sampling dan rumus slovin sehingga didapatkan 114 orang untuk dijadikan sampel dalam penelitian ini. Kuesioner yang disebarkan terdiri dari dua instrumen yaitu berdasarkan dimensi metode EUCS dan E-ServQual. Tujuan dari penelitian ini adalah untuk mengetahui persentase tingkat kepuasan dosen dalam menerapkan openlearning untuk proses perkuliahan online yang diukur dengan komparasi analisis pendekatan metode EUCS dan E-ServQual serta gap antara kedua kuesioner tersebut, sehingga harapannya dapat memberikan hasil rekomendasi bagi Universitas Muhammadiyah Kalimantan Timur untuk mengevaluasi keberhasilan perkuliahan online yang sudah berjalan. Hasil penelitian menunjukan bahwa tingkat kepuasan dosen UMKT dalam perkuliahan online berbasis LMS Openlearning menggunakan metode EUCS sebesar 78,33\% dengan selisih sebesar 9,98\% sedangkan saat menggunakan metode E-ServQual tingkat kepuasan pengguna sebesar 73,15\% dengan selisih sebesar 8\%. Dari hasil analisis komparasi kedua metode tersebut didapatkan persentase kepuasan pengguna menggunakan metode EUCS lebih tinggi daripada metode E-ServQual walaupun memiliki range kategori yang sama yakni puas.
\end{abstract}

Kata kunci: Learning Management System, E-Servqual, EUCS, Kepuasan Pengguna 


\section{PENDAHULUAN}

Universitas Muhammadiyah Kalimantan Timur (UMKT) merupakan salah satu universitas yang mengusung konsep IT-Based Paperless University berupaya untuk meningkatkan kualitas pendidikan demi mencetak lulusan-lulusan yang berkualitas meskipun di tengah wabah virus Covid19. Tidak heran jika UMKT memberlakukan sistem pembelajaran berbasis online bekerja sama dengan penyedia layanan platform Learning Management System (LMS) "Openlearning.com Australia" demi memenuhi kebutuhan pembelajaran perkuliahan di masa pandemi Covid-19 yang berkualitas.

Openlearning merupakan platform pembelajaran online LMS yang mengedepankan penyampaian konten pembelajaran kepada mahasiswa dan mendukung berbagai macam media bahan ajar dosen atau tenaga pengajar dalam bentuk teks, gambar, video, audio serta fitur diskusi layaknya sosial media yang memudahkan dosen dan mahasiswa untuk berinteraksi secara interaktif dalam menunjang proses pembelajaran atau perkuliahan secara daring (online). Fitur yang ditawarkan oleh openlearning dirasa UMKT cukup mumpuni mulai dari kemudahan dalam mengakses aplikasi yang mampu mensupport semua jenis device atau perangkat komputer dan smartphone hingga jenis sistem operasi yang digunakan, kemudahan pengaturan jadwal dan melihat progress perkuliahan setiap matakuliah, manajemen kelas dan mahasiswa, sampai pada proses assessment hasil akhir perkuliahan.

Untuk terus bisa melakukan evaluasi kualitas penyelenggaraan perkuliahan online di UMKT, dirasa perlu diadakannya analisis tingkat kepuasan dosen sebagai pengguna sistem berbasis Learning Management System (LMS) Openlearning.com. Dimana sejak pertama kali diterapkan di UMKT belum pernah dilaksanakan analisis mengenai tingkat kepuasan dosen terhadap Openlearning. Hal ini penting dilaksanakan untuk mengetahui sejauh mana harapan dan persepsi dosen UMKT dalam penggunaan dan untuk perkembangan fasilitas serta fitur-fitur yang tersedia pada platform LMS Openlearning. Analisis tingkat kepuasan pengguna LMS Openlearning bagi dosen UMKT sangat dibutuhkan untuk mengukur kepuasan dosen selama menggunakan platform Openlearning sebagai media pembelajaran online. Karena dengan baiknya sebuah platform e-learning, diharapkan dapat mendukung dosen untuk meningkatkan kualitas pembelajaran, dan rekomendasi kepada pihak manajemen kampus dan pengembang platform Openlearning untuk dilakukan evaluasi yang lebih baik

Ada beberapa metode yang dapat diterapkan dalam mengukur tingkat kepuasan pengguna terhadap sistem informasi seperti EServQual, End-User Computing Satisfaction (EUCS), Technology Acceptance Model (TAM), WebQual 4.0, dll. Berikut beberapa penelitian yang telah dilakukan peneliti dalam mengukur tingkat kepuasan pengguna terhadap suatu sistem.

M. Suryawan dan Prihandoko, 2015, melakukan penelitian untuk mengetahui tingkat kepuasan pengguna terhadap Sistem Informasi Akademik (SIAKAD) Politeknik Negeri Madiun (PNM) menggunakan metode TAM dan EUCS. Hasil penelitian ini adalah SIAKAD PNM dapat diterima oleh pengguna dilihat dari aspek 
persepsi kemudahan dan persepsi kemanfaatan baik secara simultan dan secara individual [1].

Medyantiwi, 2021, melakukan analisis terhadap kualitas layanan portal akademik pada FKIP Universitas Riau menggunakan metode EServQual dengan perhitungan Customer Satisfaction Index (CSI). Berdasarkan hasil perhitungan pada setiap dimensi E-ServQual, nilai tertinggi terdapat pada dimensi daya tanggap sebesar 2,50 untuk persepsi dan dimensi efisiensi sebesar 3,03 untuk ekpetasi sedangkan nilai terendah untuk persepsi terdapat pada dimensi privasi sebesar 1,13 dan untuk ekspetasi terdapat pada dimensi privasi sebesar 1,36 [2].

Dian Novita dan Dewi Suhartin Ningsih, 2020, dalam penelitian ini dilakukan pengukuran tingkat kepuasan pengguna e-learning Vilep di Poltekkes Kemenkes Palembang menggunakan metode EUCS. Hasil penelitian ini menunjukan bahwa tingkat kepuasan pengguna e-learning Vilep secara simultan semua variable terpenuhi dan dari analisis korelasi menunjukan bahwa variable satisfaction dapat dijelaskan oleh variabel content, accuracy, format, ease of use dan timeliness sebesar 85,4\% [3].

Diana, 2015, melakukan evaluasi terhadap kualitas layanan sistem informasi. Pengukuran kepuasan berdasarkan pada dimensi E-ServQual dengan parameter, yaitu bukti langsung, keandalan, daya tanggap, jaminan serta empati. Hasil dari penelitian menunjukan bahwa prioritas perbaikan yang harus dilakukan adalah kemudahan sistem informasi untuk dioperasikan, keunikan kreatifitas rancangan sistem informasi, dan kemampuan sistem dalam memberikan informasi yang akurat [4].
Kemudian penelitian yang dilakukan oleh Finda, 2020, yaitu mengevaluasi tingkat kepuasan pengguna Online Public Access Catalogue (OPAC) di perpustakaan Universitas Riau menggunakan metode EUCS. Kesimpulan dari penelitian ini, yakni pengguna merasa puas dengan penerapan sistem OPAC di Universitas Riau. Hal ini dibuktikan dengan nilai t-statistik content (48,813), accuracy $(35,155)$, format $(8,100)$, ease of use $(4,184)$, dan timeliness $(22,029)$ lebih besar nilai T tabel [5].

T. Husain dan Agus Budiyantara, 2018, melakukan penelitian terhadap tingkat kepuasan pengguna website Sekolah Tinggi ABC. Dalam penelitian ini digunakan metode EUCS dan WebQual 4.0 yang terdiri dari dimensi usability, information quality dan services interaction. Hasil dari penelitian ini diperoleh bahwa metode EUCS berpengaruh signifikan terhadap kepuasan pengguna sedangkan metode Webqual 4.0 melalui dimensi usability dan service inveraction berpengaruh signifikan terhadap kepuasan pengguna [6].

Dari beberapa penelitian sebelumnya belum ada yang melakukan komparasi terhadap metode E-ServQual dan EUCS dalam mengukur tingkat kepuasan pengguna terhadap suatu sistem informasi. Dari hal tersebut maka penelitan ini dilakukan pengukuran tingkat kepuasan dosen UMKT dalam penggunaan LMS Openlearning pada perkuliahan online di masa pandemi covid19 menggunakan metode E-ServQual dan EUCS. Penelitian ini diharapkan dapat membandingkan tingkat kepuasan dosen dari dua metode dan menganalisis gap antara kedua kuesioner tersebut, sehingga mampu memberikan 
rekomendasi berdasarkan persepsi dosen dalam menggunakan Openlearning dengan lebih baik dibandingkan hanya dengan satu buah pendekatan metode saja.

\section{METODOLOGI PENELITIAN}

Jenis penelitian yang digunakan deskriptif dengan skema seperti terlihat pada gambar 1 .

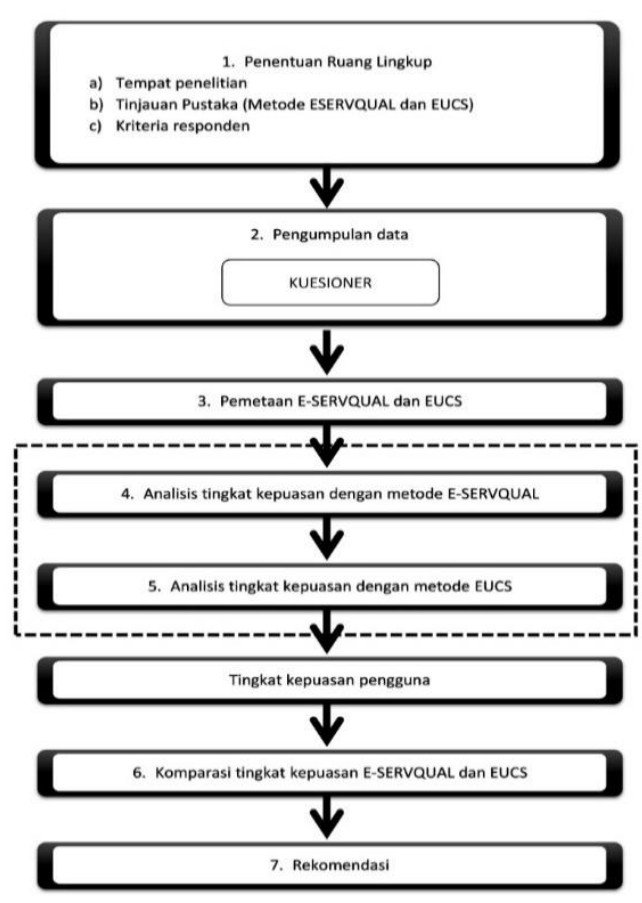

Gambar 1. Metode Penelitian

\subsection{Penentuan Responden Kuesioner}

Penentuan responden kuesioner menggunakan teknik random sampling dan rumus slovin. Responden tersebut adalah seluruh dosen yang berNIDN serta aktif mengajar di UMKT. Jumlah responden dalam penelitian ini ditentukan dengan rumus Slovin [7] yaitu:

$$
\begin{aligned}
& n=\frac{N}{1+N e^{2}} \\
& n=\frac{160}{1+160(0,05)^{2}} \\
& n=114
\end{aligned}
$$

Keterangan:

$\mathrm{n}=$ jumlah sampel

$\mathrm{N}=$ ukuran populasi

$\mathrm{e}=$ persentase kelonggaran ketidaktelitian karena kesalahan sampel yang masih bisa ditolelir 5\%

Dari penetuan sampel menggunakan rumus slovin yang telah dilakukan sebelumnya maka didapatkan 114 dosen dari total 160 dosen yang ber-NIDN serta aktif mengajar di Universitas Muhammadiyah Kalimantan Timur untuk dijadikan sampel dalam penelitian ini.

\subsection{Metode Pengumpulan Data}

Metode pengumpulan data yang digunakan pada penelitian ini dilakukan penyebaran kuesioner di komunitas media sosial internal kampus demi memperoleh informasi mengenai penilaian responden. Proses ini dilakukan dengan menggunakan Google Form.

\subsection{Instrumen Penelitian}

Instrumen penelitian adalah sarana dalam penelitian untuk mengumpulkan data. Pedoman kuesioner dibuat dalam bentuk option menggunakan Google Form dengan merujuk pada dimensi yang ada pada metode EUCS dan E-ServQual. Hubungan antara pertanyaan yang ada di kuesioner dengan dimensi pada metode EUCS bisa dilihat pada tabel 1, sementara untuk hubungan pertanyaan yang ada di kuesioner dengan dimensi pada metode E-ServQual bisa dilihat pada tabel 2 . 
Tabel 1. Hubungan pertanyaan kuesioner dengan dimensi EUCS

\begin{tabular}{|c|c|c|c|}
\hline $\begin{array}{c}\text { Variabel } \\
\text { Penelitian }\end{array}$ & Dimensi & $\begin{array}{c}\text { Nomor } \\
\text { pertanyaan } \\
\text { kuesioner }\end{array}$ & $\begin{array}{c}\text { Jumlah item } \\
\text { pertanyaan }\end{array}$ \\
\hline \multirow{5}{*}{ Openlearning } & Content & $1-6$ & 6 \\
\hline & Accuracy & $7-9$ & 3 \\
\hline & Format & $10-13$ & 4 \\
\hline & Ease of use & $14-19$ & 6 \\
\hline & Timeliness & $20-22$ & 3 \\
\hline
\end{tabular}

(Sumber: Data diolah, 2021)

Tabel 2. Hubungan pertanyaan kuesioner dengan dimensi E-ServQual

\begin{tabular}{cccc}
\hline $\begin{array}{c}\text { Variabel } \\
\text { Penelitian }\end{array}$ & Dimensi & $\begin{array}{c}\text { Nomor } \\
\text { pertanyaan } \\
\text { kuesioner }\end{array}$ & $\begin{array}{c}\text { Jumlah item } \\
\text { pertanyaan }\end{array}$ \\
\hline \multirow{4}{*}{ Openlearning } & Tangible & $1-2$ & 2 \\
& Reliability & $3-7$ & 5 \\
Responsive & $8-10$ & 3 \\
& ness & & 3 \\
& Assurance & $11-13$ & 6 \\
\hline & Empathy & $14-19$ & \\
\hline
\end{tabular}

(Sumber: Data diolah, 2021)

\subsection{Pengukuran Interval Jawaban Responden}

Kuesioner yang digunakan dalam penelitian ini adalah kuesioner dengan instrumen skala likert. Dengan skala likert, maka variabel yang akan diukur dijabarkan menjadi indikator variabel. Kemudian indikator tersebut dijadikan titik tolak untuk menyusun item - item instrumen yang dapat berupa pernyataan atau pertanyaan. Jawaban setiap item instrumen yang menggunakan skala likert mempunyai gradiasi dari yang sangat positif sampai sangat negatif, yang dapat berupa kata kata [7]. Berikut adalah tabel 3 yang menunjukkan kriteria penilaian untuk item pertanyaan kuesioner.
Tabel 3. Kriteria Penilaian

\begin{tabular}{cccc}
\hline No & Simbol & Kriteria Penilaian & Skor \\
\hline 1 & SP & SANGAT PUAS & 5 \\
2 & P & PUAS & 4 \\
3 & CP & CUKUP PUAS & 3 \\
4 & TP & TIDAK PUAS & 2 \\
5 & STP & SANGAT & 1 \\
\multicolumn{4}{l}{ TIDAK PuU PUS } \\
Siregar, 2017)
\end{tabular}

Kemudian jawaban responden akan diubah kedalam bentuk rentang skala. Untuk menentukan rentang skala (RS), digunakan rumus sebagai berikut [8]:

$R S=\frac{m-n}{b}$

Keterangan:

$\mathrm{RS}=$ rentang skala

$\mathrm{m}=$ Skor tertinggi dalam pengukuran (5)

$\mathrm{n}=$ Skor terendah dalam pengukuran (1)

$\mathrm{b}=$ Jumlah kategori yang dibuat (5)

Berdasarkan rumus tersebut, diperoleh perhitungan rentang skala sebagai berikut:

$R S=\frac{5-1}{5}$

$R S=0,8$

Kemudian skor dapat diinterpretasikan dengan interval skor pada tabel 4.

Tabel 4. Interval Skor

\begin{tabular}{cc}
\hline Interval & Kriteria \\
\hline $4,2-5,0$ & Sangat Puas \\
$3,4-4,1$ & Puas \\
$2,6-3,3$ & Cukup Puas \\
$1,8-2,5$ & Tidak Puas \\
$1,0-1,7$ & Sangat Tidak Puas \\
\hline \multicolumn{2}{l}{ (Sumber: Data diolah, 2021) }
\end{tabular}

Dari tabel diatas, dapat disimpulkan dari hasil yang diperoleh bahwa batas tertinggi adalah 5 dan batas terendah adalah 1. Untuk setiap pertanyaan yang berhubungan dengan platform Openlearning diukur dengan mengkategorikan kriteria tingkat kepuasan 
pengguna dengan sangat puas hingga sangat tidak puas.

\subsection{Analisis Tingkat Kepuasan}

Agar dapat mengetahui tingkat kepuasan pada item - item pertanyaan yang sesuai dengan dimensi metode EUCS ataupun metode EServQual yaitu dengan menghitung total skor kriteria serta persentase kepuasan pengguna. Berikut langkah - langkah yang dilakukan:

a. Menentukan besarnya skor kriteria (skor ideal $),\left(\sum \mathrm{SK}\right) \sum \mathrm{SK}=$ skor tertinggi setiap item $\mathrm{x}$ jumlah item pertanyaan $\mathrm{x}$ jumlah responden.

b. Menentukan jumlah skor total hasil pengumpulan data variabel $\left(\sum \mathrm{SH}\right)$

c. Mencari besarnya persentase (p)

$p=\frac{\sum S H}{\sum S K} \times 100 \%$

Setelah itu interval persentase tingkat kepuasan pengguna diinterpretasikan pada tabel 5, kriterianya adalah sangat puas, puas, cukup puas, tidak puas, serta sangat tidak puas [9].

\section{Tabel 5. Interpretasi persentase tingkat} kepuasan pengguna

\begin{tabular}{cc}
\hline Interval & Kriteria \\
\hline $81 \%-100 \%$ & Sangat Puas \\
$61 \%-80 \%$ & Puas \\
$41 \%-60 \%$ & Cukup Puas \\
$21 \%-40 \%$ & Tidak Puas \\
\hline Interval & Kriteria \\
\hline $0 \%-20 \%$ & Sangat Tidak Puas \\
\hline \multicolumn{2}{l}{ (Sumber: Setyoningrum, 2020) }
\end{tabular}

\subsection{Alur Penelitian}

Adapun alur penelitian merupakan langkah - langkah yang harus dilakukan dalam penelitian hingga mencapai suatu kesimpulan, tahapan alur penelitian dari analisis kepuasan pengguna dengan metode EUCS dan E-ServQual terlihat pada Gambar 2.

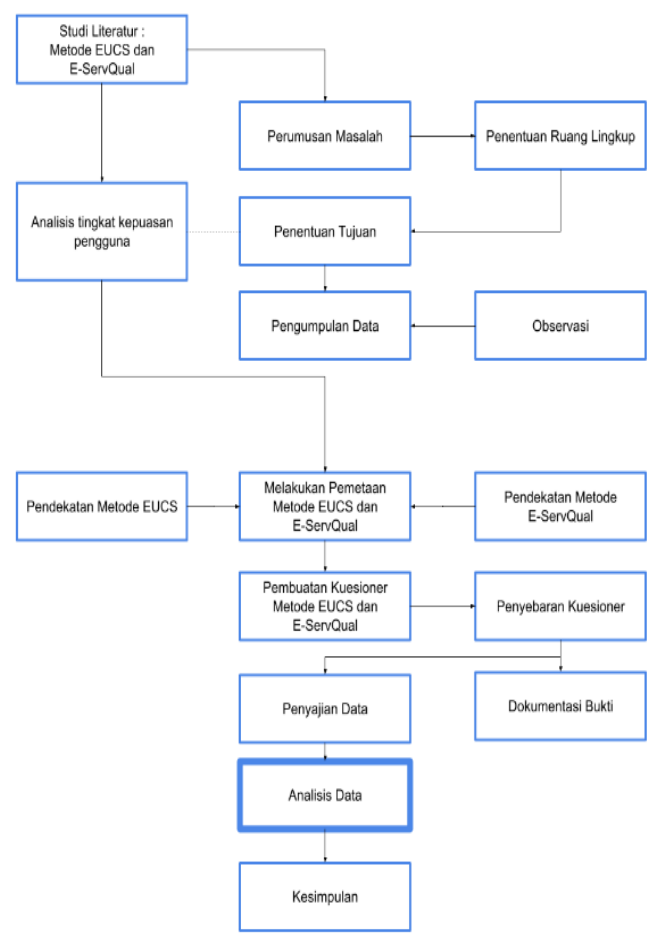

Gambar 2. Alur Penelitian

\section{HASIL DAN PEMBAHASAN}

\subsection{Pengumpulan Data}

Penelitian ini dilakukan pada lingkup dosen Universitas Muhammadiyah Kalimantan Timur (UMKT) yang aktif dan pernah menggunakan Openlearning dalam menerapkan perkuliahan online. Untuk keperluan data yang digunakan pada penelitian ini disebar kuesioner secara online kepada objek penelitian yakni dosen UMKT yang pernah menggunakan Openlearning melalui aplikasi Google Form. Hal ini dilakukan karena wabah covid-19 yang masih melanda dunia khususnya Indonesia untuk menjaga protokol kesehatan. 


\subsection{Rancangan Kuesioner Metode EUCS}

Sebelum kuesioner disebar kepada responden dilakukan perancangan kuesioner menggunakan dimensi pada metode EUCS dan E-ServQual dimana penilaian berdasarkan persepsi harapan dan kenyataan pengguna dalam hal ini Dosen UMKT. Di dalam metode EUCS terdapat lima dimensi sebagai bahan penilaian yaitu content (isi), accuracy (keakuratan), format (format), ease of use (mudah digunakan) dan timeliness (waktu) [10].

\subsection{Rancangan Kuesioner Metode E- ServQual}

Dalam melakukan analisis tingkat kepuasan pengguna menggunakan metode EServQual terdapat lima dimensi yaitu tangibles, reliability, responsiveness, assurance dan empathy [11]. Dengan adanya analisis menggunakan metode EUCS dan E-ServQual maka dapat diperoleh komparasi hasil analisis antara kedua metode tersebut.

\subsection{Pengolahan Data Kuesioner}

Kuesioner yang telah disebarkan kepada responden selanjutnya akan diproses untuk mendapatkan hasil dari analisis tingkat kepuasan dosen dalam perkuliahan online pada masa pandemi covid-19 berbasis LMS di UMKT menurut persepsi dan harapan pengguna. Sesuai penjelasan pada analisis tingkat kepuasan responden bahwa interval persentase tingkat kepuasan pengguna diinterpretasikan seperti terlihat pada tabel 5 .

Selanjutnya kuesioner tersebut disebarkan secara online kepada objek penelitian yakni dosen UMKT yang pernah menggunakan
Openlearning melalui aplikasi Google Form dengan tujuan untuk mengetahui sejauh mana persepsi dan harapan pengguna sesuai dengan dimensi pada metode EUCS dan E-ServQual.

\subsection{Analisis Hasil Metode EUCS}

Dari hasil rekapitulasi kuesioner dengan pendekatan metode EUCS yang telah dilakukan sebelumnya, maka diperoleh skor kriteria (skor ideal), besar persentase serta gap/selisih dari masing-masing variabel penilaian kuesioner metode EUCS. Adapun langkah - langkah pada masing - masing sebagai berikut :

1. Menentukan skor ideal

Dalam menentukan skor kriteria (skor ideal) di setiap dimensi pada metode EUCS digunakan rumus sebagai berikut [12]:

$\sum S K=S M \times J P \times J R$

Keterangan:

$\mathrm{SM}=$ Skor maksimal

$\mathrm{JP}=$ Jumlah item pertanyaan

$\mathrm{JR}=$ Jumalah responden

Dari perhitungan tersebut nantinya akan didapatkan jarak kategori nya, contoh di dimensi content terdapat 6 item dengan skor maksimal 5 dan 114 responden maka skor idealnya 3.420, Adapun jarak kategorinya adalah sebagai berikut :

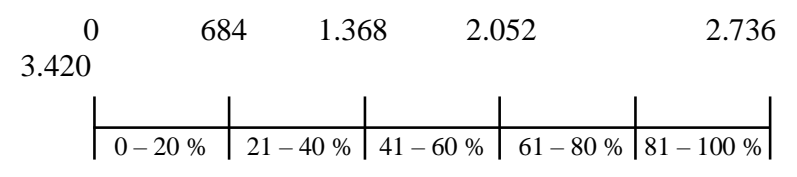

2. Menentukan besarnya persentase dari setiap dimensi.

Dari jumlah total skor pengumpulan data variabel berikutnya menentukan besarnya persentase tingkat kepuasan pengguna dengan 
membandingkan antara persepsi dan harapan pengguna yakni dosen UMKT yang pernah menggunakan Openlearning, disajikan dalam tabel 6 .

\section{Tabel 6. Persentase tingkat kepuasan pengguna dengan metode EUCS}

\begin{tabular}{|c|c|c|c|}
\hline \multirow[b]{2}{*}{ Dimensi } & \multicolumn{2}{|c|}{ Skor Total } & \multirow{2}{*}{$\begin{array}{c}\text { Tingkat } \\
\text { Kepuasan } \\
(\%)\end{array}$} \\
\hline & $\begin{array}{c}\text { Persepsi } \\
\text { Pengguna }\end{array}$ & $\begin{array}{l}\text { Harapan } \\
\text { Pengguna }\end{array}$ & \\
\hline Content & 2.857 & 3.074 & $83,54 \%$ \\
\hline Accuracy & 1.303 & 1.527 & $76.2 \%$ \\
\hline Format & 1.979 & 2.012 & $86.8 \%$ \\
\hline $\begin{array}{c}\text { Ease of } \\
\text { Use }\end{array}$ & 2.374 & 2.940 & $69.41 \%$ \\
\hline $\begin{array}{c}\text { Timelines } \\
s\end{array}$ & 1.310 & 1.522 & $76.61 \%$ \\
\hline
\end{tabular}

Hasil analisis tingkat kepuasan responden terhadap kinerja dan harapan dari setiap variabel di atas dapat diproses lebih lanjut untuk menemukan nilai gap/selisih pada setiap dimensi. Hal tersebut dilakukan untuk dapat dilakukan evaluasi terhadap LMS Openlearning. Nilai gap/selisih di setiap dimensi dapat dilihat pada tabel 7.

Tabel 7. Nilai gap/selisih di setiap dimensi pada metode EUCS

\begin{tabular}{|c|c|c|c|}
\hline \multirow[b]{2}{*}{ Dimensi } & \multicolumn{2}{|c|}{ Skor Total } & \multirow{2}{*}{$\begin{array}{c}\text { GAP/ } \\
\text { Selisih (\%) }\end{array}$} \\
\hline & $\begin{array}{c}\text { Persepsi } \\
\text { Pengguna }\end{array}$ & $\begin{array}{c}\text { Harapan } \\
\text { Pengguna }\end{array}$ & \\
\hline Content & 2.857 & 3.074 & $5,77 \%$ \\
\hline Accuracy & 1.303 & 1.527 & $12,59 \%$ \\
\hline Format & 1.979 & 2.012 & $2,06 \%$ \\
\hline $\begin{array}{c}\text { Ease of } \\
\text { Use }\end{array}$ & 2.374 & 2.940 & $16,55 \%$ \\
\hline Timeliness & 1.310 & $12,40 \%$ & $12,40 \%$ \\
\hline
\end{tabular}

(Sumber: Hasil Pengelohan Data, 2021)

Berdasarkan tabel 7, total tingkat kepuasan yang dirasakan dosen UMKT dalam perkuliahan online pada masa pandemi covid-19 berbasis LMS Openlearning menggunakan pendekatan metode EUCS sebesar 78,33\% dengan gap/selisih sebanyak $9,98 \%$ artinya pengguna dalam hal ini dosen UMKT berada pada rentang kategori puas. Dari kelima dimensi tersebut variabel format memiliki gap/selisih terkecil, yakni sebesar $1,45 \%$ sedangkan gap/selisih terbesar ada pada variabel ease of use, yakni sebesar $16,55 \%$.

\subsection{Analisis Hasil metode E-ServQual}

Berdasarkan rekapitulasi kuesioner dengan pendekatan metode E-ServQual yang telah dilakukan sebelumnya, maka diperoleh skor kriteria (skor ideal), besarnya persentase serta gap/selisih dari setiap variabel penilaian kuesioner metode E-ServQual. Adapun langkah langkah pada setiap dimensi sebagai berikut:

1. Menentukan skor ideal

Dalam menentukan skor kriteria (skor ideal) di setiap dimensi pada metode E-ServQual digunakan rumus yang sama seperti persamaan 4 sebelumnya.

Dari perhitungan tersebut nantinya akan didapatkan jarak kategori nya, contoh di dimensi tangible terdapat 2 item dengan skor maksimal 5 dan 114 responden maka skor idealnya 1140, Adapun jarak kategorinya adalah sebagai berikut :

$\begin{aligned} & 0 \\
& 1.140\end{aligned}$
\begin{tabular}{|l|l|l|l|l|} 
& 228 & 456 & 684 & \\
& & & & \\
\hline $0-20 \%$ & $21-40 \%$ & $41-60 \%$ & $61-80 \%$ & $81-100 \%$
\end{tabular}

2. Menentukan besarnya persentase dari setiap dimensi.

Dari jumlah total skor pengumpulan data variabel berikutnya menentukan besarnya persentase tingkat kepuasan pengguna dengan membandingkan antara persepsi dan harapan pengguna yakni dosen UMKT yang pernah menggunakan Openlearning, disajikan dalam tabel 8 . 
Tabel 8. Persentase tingkat kepuasan pengguna dengan metode E-ServQual

\begin{tabular}{|c|c|c|c|}
\hline \multirow[b]{2}{*}{ Dimensi } & \multicolumn{2}{|c|}{ Skor Total } & \multirow{2}{*}{$\begin{array}{c}\text { Tingkat } \\
\text { Kepuasan } \\
(\%)\end{array}$} \\
\hline & $\begin{array}{c}\text { Persepsi } \\
\text { Pengguna }\end{array}$ & $\begin{array}{c}\text { Harapan } \\
\text { Pengguna }\end{array}$ & \\
\hline Tangible & 897 & 996 & $78,68 \%$ \\
\hline Reliability & 1.936 & 2.324 & $67,93 \%$ \\
\hline $\begin{array}{c}\text { Responsive } \\
\text { ness }\end{array}$ & 1.342 & 1.404 & $78,48 \%$ \\
\hline Assurance & 1.294 & 1.344 & $75,67 \%$ \\
\hline Empathy & 2.453 & 2.720 & $71,73 \%$ \\
\hline
\end{tabular}

(Sumber: Hasil Pengelohan Data, 2021)

Hasil analisis tingkat kepuasan responden terhadap kinerja dan harapan dari setiap variabel di atas dapat diproses lebih lanjut untuk menemukan nilai gap/selisih pada setiap dimensi. Hal tersebut dilakukan untuk dapat dilakukan evaluasi terhadap LMS Openlearning. Nilai gap/selisih di setiap dimensi dapat dilihat pada tabel 9.

Tabel 9. Nilai gap/selisih di setiap dimensi pada metode E-ServQual

\begin{tabular}{cccc}
\hline \multirow{2}{*}{ Dimensi } & \multicolumn{2}{c}{ Skor Total } & $\begin{array}{c}\text { GAP/ } \\
\text { Selisih (\%) }\end{array}$ \\
\cline { 2 - 4 } & $\begin{array}{c}\text { Persepsi } \\
\text { Pengguna }\end{array}$ & $\begin{array}{c}\text { Harapan } \\
\text { Pengguna }\end{array}$ & \\
\hline Tangible & 897 & 996 & $78,68 \%$ \\
Reliability & 1.936 & 2.324 & $67,93 \%$ \\
Responsiveness & 1.342 & 1.404 & $78,48 \%$ \\
Assurance & 1.294 & 1.344 & $75,67 \%$ \\
Empathy & 2.453 & 2.720 & $71,73 \%$ \\
\hline
\end{tabular}

(Sumber: Hasil Pengelohan Data, 2021)
Berdasarkan tabel 9, total tingkat kepuasan yang dirasakan dosen UMKT dalam perkuliahan online pada masa pandemi covid-19 berbasis LMS Openlearning menggunakan pendekatan metode E-ServQual sebesar 73,15\% dengan gap/selisih sebanyak $8 \%$ artinya pengguna dalam hal ini dosen UMKT berada pada rentang kategori puas. Dari kelima dimensi tersebut variabel assurance memiliki gap/selisih terkecil, yakni sebesar $3,63 \%$ sedangkan gap/selisih terbesar ada pada variabel reliability, yakni sebesar $13,61 \%$.

\subsection{Komparasi Pengukuran Tingkat Kepuasan Menggunakan Metode EUCS dan E-ServQual}

Berdasarkan analisis tingkat kepuasan responden terhadap persepsi dan harapan pengguna dengan menggunakan metode EUCS dan E-ServQual memiliki nilai yang sama -sama pada rentang kategori puas. Selain persamaan dalam hasil tersebut, ada perbedaan dari beberapa aspek, yang dapat dilihat pada tabel 10 .

Tabel 10. Komparasi hasil analisis tingkat kepuasan

\begin{tabular}{|c|c|c|}
\hline \multirow[b]{2}{*}{ No } & \multirow[b]{2}{*}{ Aspek } & Komparasi Hasil Analisis \\
\hline & & Metode E-ServQual \\
\hline 1 & Dimensi & $\begin{array}{l}\text { Dimensi yang diukur: content, accuracy, format, Dimensi yang diukur: tangible, reliability, } \\
\text { ease of use, dan timeliness } \\
\text { responsiveness, assurance, dan empathy }\end{array}$ \\
\hline 2 & $\begin{array}{c}\text { Hasil } \\
\text { Analisis }\end{array}$ & $\begin{array}{l}\text { Total tingkat kepuasan yang dirasakan pengguna Total tingkat kepuasan yang dirasakan } \\
\text { sebesar } 78,33 \% \text { dengan gap/selisih sebesar pengguna sebesar } 73,15 \% \text { dengan gap/selisih } \\
9,98 \% \text { artinya pengguna berada pada rentang sebesar } 8 \% \text { artinya pengguna berada pada } \\
\text { kategori puas. Dari kelima dimensi tersebut rentang kategori puas. Dari kelima dimensi } \\
\text { variabel format memiliki gap/selisih terkecil tersebut variabel assurance memiliki } \\
\text { yakni } 1,45 \% \text { sedangkan gap/selisih terbesar ada gap/selisih terkecil yakni } 2,92 \% \text { sedangkan } \\
\text { pada variabel ease of use yakni sebesar } 16,55 \% \text { gap/selisih terbesar ada pada variabel } \\
\text { reliability yakni sebesar } 13,61 \% \text {. }\end{array}$ \\
\hline 3 & $\begin{array}{c}\text { Variabel } \\
\text { Perbaikan }\end{array}$ & $\begin{array}{l}\text { Dengan gap/selisih terbesar pada variabel ease of Dengan gap/selisih terbesar pada variabel } \\
\text { use maka terkait dengan masalah kemudahan reliability maka keandalan sistem dalam } \\
\text { pengguna harus diperbaiki atau dievaluasi } \\
\text { memberikan informasi kepada pengguna } \\
\text { harus diperbaiki atau dievaluasi }\end{array}$ \\
\hline
\end{tabular}

(Sumber: Data diolah, 2021) 


\subsection{Panduan Perbaikan}

Berdasarkan uraian di atas, analisis tingkat kepuasan baik dengan metode EUCS maupun metode E-ServQual akan menghasilkan rekomendasi bagi pihak institusi. Adapun panduan perbaikan dilakukan dengan melihat nilai rata-rata responden dari setiap pertanyaan yang diajukan melalui kuesioner. Nilai dari masing-masing pertanyaan pada tiap dimensi dengan jumlah responden berjumlah 114 responden seperti tersaji dalam tabel 11 .

Tabel 11 Hasil nilai rata-rata item pertanyaan kuesioner

\begin{tabular}{|c|c|c|c|}
\hline No & Pertanyaan & $\begin{array}{c}\text { Rata-rata } \\
\text { nilai } \\
\text { responden }\end{array}$ & $\begin{array}{c}\text { Kriteria } \\
\text { penialian }\end{array}$ \\
\hline \multicolumn{4}{|c|}{ Metode EUCS } \\
\hline 1 & & Content & \\
\hline 1.1 & P1 & 4.42 & Sangat Puas \\
\hline 1.2 & P2 & 4.06 & Sangat Puas \\
\hline 1.3 & P3 & 4.13 & Sangat Puas \\
\hline 1.4 & P4 & 4.07 & Sangat Puas \\
\hline 1.5 & P5 & 4.12 & Sangat Puas \\
\hline 1.6 & P6 & 4.25 & Sangat Puas \\
\hline 2 & \multicolumn{3}{|c|}{ Accuracy } \\
\hline 2.1 & P1 & 3.82 & Puas \\
\hline 2.2 & P2 & 3.92 & Puas \\
\hline 2.3 & P3 & 3.69 & Puas \\
\hline 3 & \multicolumn{3}{|c|}{ Format } \\
\hline 3.1 & P1 & 4 & Puas \\
\hline 3.2 & $\mathrm{P} 2$ & 4.19 & Sangat Puas \\
\hline 3.3 & P3 & 4.52 & Sangat Puas \\
\hline 3.4 & P4 & 4.65 & Sangat Puas \\
\hline 4 & \multicolumn{3}{|c|}{ Ease of use } \\
\hline 4.1 & P1 & 3.99 & Puas \\
\hline 4.2 & P2 & 3.31 & Puas \\
\hline 4.3 & P3 & 3.4 & Puas \\
\hline 4.4 & P4 & 3.32 & Puas \\
\hline 4.5 & P5 & 3.29 & Puas \\
\hline 4.6 & P6 & 3.52 & Puas \\
\hline 5 & \multicolumn{3}{|c|}{ Timeliness } \\
\hline 5.1 & P1 & 4.02 & Sangat Puas \\
\hline 5.2 & P2 & 3.82 & Puas \\
\hline 5.3 & P3 & 3.65 & Puas \\
\hline
\end{tabular}

\begin{tabular}{|c|c|c|c|}
\hline No & Pertanyaan & $\begin{array}{c}\text { Rata-rata nilai } \\
\text { responden }\end{array}$ & $\begin{array}{c}\text { Kriteria } \\
\text { penialian }\end{array}$ \\
\hline \multicolumn{4}{|c|}{$\begin{array}{c}\text { Metode E-ServQual } \\
\text { Tangible }\end{array}$} \\
\hline 1.1 & P1 & 4.11 & Sangat Puas \\
\hline 1.2 & P2 & 3.75 & Puas \\
\hline 2 & & Reliability & \\
\hline 2.1 & P1 & 3.54 & Puas \\
\hline 2.2 & P2 & 2.45 & ukup Pui \\
\hline 2.3 & P3 & 3.65 & Puas \\
\hline 2.4 & P4 & 3.53 & Puas \\
\hline 2.5 & P5 & 3.82 & Puas \\
\hline 3 & \multicolumn{3}{|c|}{ Responsiveness } \\
\hline 3.1 & P1 & 3.99 & Puas \\
\hline 3.2 & P2 & 3.64 & Puas \\
\hline 3.3 & P3 & 4.14 & Sangat Puas \\
\hline 4 & \multicolumn{3}{|c|}{ Assurance } \\
\hline 4.1 & P1 & 4.12 & Sangat Puas \\
\hline 4.2 & P2 & 4.32 & Sangat Puas \\
\hline 4.3 & P3 & 2.91 & Cukup Puas \\
\hline 5 & \multicolumn{3}{|c|}{ Empathy } \\
\hline 5.1 & P1 & 3.7 & Puas \\
\hline 5.2 & P2 & 3.83 & Puas \\
\hline 5.3 & P3 & 3.73 & Puas \\
\hline 5.4 & P4 & 3.61 & Puas \\
\hline 5.5 & P5 & 3.09 & Puas \\
\hline 5.6 & P6 & 3.56 & Puas \\
\hline
\end{tabular}

(Sumber: Hasil Pengolahan Data, 2021)

Berdasarkan tabel 11 tersebut nilai rata rata yang diperoleh dari hasil penyebaran kuesioner, diketahui bahwa beberapa pertanyaan pada tiap dimensi sudah berada pada nilai angka 3,4 ke atas yang artinya dalam kategori puas tetapi terdapat beberapa nilai yang masih perlu diperhatikan karena berada pada nilai dibawah 3,4 artinya cukup puas dan perlu perbaikan. Adapun beberapa hal yang perlu diperbaiki dapat dilihat pada tabel 12 . 
Tabel 12 Rekomendasi

\begin{tabular}{|c|c|c|}
\hline No & Dimensi & Saran perbaikan \\
\hline 1 & $\begin{array}{l}\text { Reliability pada bagian } \\
\text { waktu loading saat } \\
\text { membuka Openlearning }\end{array}$ & $\begin{array}{l}\text { a. Membuat blueprint IT, mengenai spesifikasi perangkat server sesuai dengan } \\
\text { kebutuhan } \\
\text { b. Penyediaan UPS untuk mengantisipasi saat terjadi pemadaman listrikagar } \\
\text { jaringan tidak down dan aplikasi tidak mengalami error } \\
\text { c. Perlunya control pada bagian pusat komputer terhadap perangkat yang } \\
\text { digunakan untuk segera mengganti perangkat lama yang sudah using } \\
\text { d. Melakukan upgrade hardisk dan RAM } \\
\text { e. Melakukan restart server agar server tidak berat ketika akan diakses }\end{array}$ \\
\hline 2 & $\begin{array}{l}\text { Responsiveness } \\
\text { bagian pelayanan } \\
\text { admin }\end{array}$ & $\begin{array}{l}\text { Menambahkan helpdesk yang dapat berbahasa Indonesia di dalam } \\
\text { Openlearning atau dengan memanfaatkan teknologi chatbot dalam } \\
\text { memberikan pelayanan terhadap dosen }\end{array}$ \\
\hline 3 & $\begin{array}{l}\text { Responsiveness pada } \\
\text { penggunaan teknologi } \\
\text { baru yang menjamin } \\
\text { keamanan ujian }\end{array}$ & $\begin{array}{l}\text { a. Membuat blueprint IT, mengenai spefikasi ujian online sesuai denhan } \\
\text { kebutuhan. } \\
\text { b. Menambahkan fitur ujian online yang memiliki kelebihan saat melaksanaka } \\
\text { ujian mahasiswa tidak dapat mengakses aplikasi apapum untuk mencari } \\
\text { jawaban }\end{array}$ \\
\hline
\end{tabular}

(Sumber: Data diolah, 2021)

\subsection{Implikasi Penelitian}

Implikasi penelitian mengenai analisis tingkat kepuasan dosen UMKT dalam perkuliahan online pada masa pandemi covid-19 berbasis LMS Openlearning menggunakan metode EUCS dan metode E-ServQual bagi pihak manajemen, adalah memberikan laporan mengenai tingkat kepuasan dosen dalam perkuliahan online pada masa pandemi covid-19 berbasis LMS Openlearning di UMKT menggunakan metode EUCS dan metode EServQual.

Adapun implikasi terhadap bidang ilmu adalah :

1. Berdasarkan penelitian analisis tingkat kepuasan dosen dalam perkuliahan online pada masa pandemi covid-19 berbasis LMS Openlearning di Universitas Muhammadiyah Kalimantan Timur menggunakan metode EUCS dan metode E-ServQual memberikan hasil yang sama pada range kategori yaitu puas, hanya pada sisi perbaikannya.
2. Analisis tingkat kepuasan perangkat lunak berbasis website dapat dilakukan dengan menggunakan metode EUCS dan E-ServQual, dengan harapan dapat diperoleh komparasi hasil penilaian dimensi pada masing-masing metode.

\section{KESIMPULAN}

Berdasarkan hasil analisis data pada bab sebelumnya, maka diperoleh kesimpulan sebagai berikut :

1. Hasil analisis tingkat kepuasan pengguna LMS Openlearning khususnya dosen UMKT menggunakan metode EUCS menghasilkan tingkat kepuasan yang dirasakan pengguna sebesar 78,33\% dengan gap/selisih sebesar 9,98\% artinya pengguna berada pada rentang kategori puas, dimana dari kelima dimensi tersebut variabel format memiliki gap/selisih terkecil yakni $1,45 \%$ sedangkan gap/selisih terbesar ada pada variabel ease of use, yaitu sebesar $16,55 \%$. 
2. Hasil analisis tingkat kepuasan pengguna menggunakan metode E-ServQual menghasilkan tingkat kepuasan yang dirasakan pengguna sebesar $73,15 \%$ dengan gap/selisih sebesar $8 \%$ artinya pengguna berada pada rentang kategori puas, dimana dari kelima dimensi tersebut variabel assurance memiliki gap/selisih terkecil yakni $3,63 \%$ sedangkan gap/selisih terbesar ada pada variabel reliability, yaitu sebesar $13,71 \%$.

3. Komparasi hasil analisis kedua metode tersebut bahwa persentase kepuasan pengguna menggunakan metode EUCS lebih tinggi nilainya dibanding dengan metode EServQual walaupun memiliki range kategori yang sama yakni puas.

\section{DAFTAR PUSTAKA}

[1] M. B. Suryawan and P. Prihandoko, "Evaluasi Penerapan SIAKAD Politeknik Negeri Madiun Menggunakan Pendekatan TAM dan EUCS," Creat. Inf. Technol. J., vol. 4, no. 3, p. 233, 2018, doi: 10.24076/citec.2017v4i3.113.

[2] M. Rahmawita, Y. Kartika, and Megawati, "Analisis Kualitas Layanan Portal Akademik Terhadap Kepuasan Mahasiswa Menggunakan Metode E-Servqual Pada Fkip Universitas Riau," J. Ilm. Rekayasa dan Manaj. Sist. Inf., vol. 4, no. 1, pp. 6772, 2018.

[3] D. Novita, "Analisis Pengaruh Implementasi E-Learning Vilep di Poltekkes Kemenkes Palembang dengan Pendekatan EUCS," JATISI (Jurnal Tek. Inform. dan Sist. Informasi), vol. 7, no. 1, pp. 29-41, 2020, doi: 10.35957/jatisi.v7i1.290.

[4] D. Diana, "Penerapan Metode E-Servqual Untuk Evaluasi Kualitas Layanan Sistem Informasi," J. Ilm. Matrik, vol. 17, no. 1, pp. 43-52, 2015.
[5] F. K. Agustia, Evaluasi Tingkat Kepuasan Pengguna OPAC Pada Perpustakaan Universitas Riau Dengan Metode EUCS. 2020.

[6] T. Husain and A. Budiyantara, "Analisis End-User Computing Satisfaction (EUCS) Dan WebQual 4.0 Terhadap Kepuasan Pengguna," JATISI (Jurnal Tek. Inform. dan Sist. Informasi), vol. 4, no. 2, pp. 164-176, 2018, doi: 10.35957/jatisi.v4i2.99.

[7] S. Siregar, Metode penelitian kuantitatif: Dilengkapi dengan perbandingan perhitungan manual \& SPSS. Jakarta: Kencana, 2017.

[8] B. Simamora, Analisis multivariat pemasaran. Gramedia Pustaka Utama, 2005.

[9] N. R. Setyoningrum, "Analisis Tingkat Kepuasan Pengguna Sistem Informasi Kerja Praktek dan Skripsi (SKKP) Menggunakan Metode End User Computing Satisfaction (EUCS)," J. Appl. Informatics Comput., vol. 4, no. 1, pp. 1721, 2020, doi: 10.30871/jaic.v4i1.1645.

[10] W. J. Doll and G. Torkzadeh, "The Measurement of End-User Computing Satisfaction," MIS Q., pp. 259-274, 1988, [Online]. Available: https://doi.org/10.2307/248851.

[11] M. S. Omar, H. F. Ariffin, and R. Ahmad, "Service Quality, Customers' Satisfaction and the Moderating Effects of Gender: A Study of Arabic Restaurants," Procedia Soc. Behav. Sci., vol. 224, no. August, pp. 384-392, 2016, doi: 10.1016/j.sbspro.2016.05.393.

[12] K. Suprapta, "Analisis kepuasan mahasiswa terhadap sistem pemilihan konsentrasi dengan menggunakan metode EUCS," J. Sist. Dan Inform., vol. 13, no. 1, pp. 6-11, 2013, [Online]. Available: https://jsi.stikombali.ac.id/index.php/jsi/article/view/186. 